\title{
In vitro multiplication of sugarcane with different nitrogen and sucrose concentrations
}

\author{
Multiplicação in vitro de cana-de-açúcar com diferentes concentrações de \\ nitrogênio e sacarose
}

\section{Giovana Bomfim de ALCANTARA ${ }^{1}$; Marília Pereira MACHADO²; Ricardo Augusto de OLIVEIRA ${ }^{3}$; João Carlos BESPALHOK FILHO ${ }^{4}$}

\begin{abstract}
${ }^{1}$ Autor para correspondência; Doutora em Fitotecnia e Fitossanidade; Universidade Federal do Paraná; Professora do Departamento de Ciências Florestais; giobomfim@ufpr.br

2 Doutora em Fitotecnia e Fitossanidade; Universidade Federal do Paraná; Pós-doutoranda; Departamento de Fitotecnia e Fitossanidade; ma_rilia10@hotmail.com

${ }^{3}$ Doutor em Fitotecnia e Fitossanidade; Universidade Federal do Paraná; Professor do Departamento de Fitotecnia e Fitossanidade; rico.cwb75@gmail.com

${ }^{4}$ Doutor em Agricultura; Universidade Federal do Paraná; Professor do Departamento de Fitotecnia e Fitossanidade; joao.bespa@gmail.com
\end{abstract}

Recebido em: 03-07-2018; Aceito em: 23-11-2018

\begin{abstract}
Sugarcane is of great economic importance worldwide. Hence, there is great interest in the development of efficient techniques for the production of good quality, homogeneous, disease- and pest-free seedlings. One way to eliminate viruses is through meristem culture. To guarantee success during meristem culture, it is necessary to optimize the components and concentrations of the culture medium. Sucrose is an essential component in the culture medium, serving as a source of carbon and energy for the seedlings. Nitrogen, in turn, is essential in plants because it is a component of biomolecules and countless enzymes. This work evaluates the best combination of nitrogen $(75,100,125$, and $150 \%)$ and sucrose $\left(0,20,30\right.$, and $\left.40 \mathrm{~g} \mathrm{~L}^{-1}\right)$ concentrations in the in vitro multiplication and development of sugarcane cultivar RB036091. The design was completely randomized, in a factorial scheme with four replicates and five explants per experimental unit. The concentration of $20 \mathrm{~g} \mathrm{~L}^{-1}$ sucrose with $100 \%$ nitrogen, from the original formulation of the MS culture medium, provided a better response in sugarcane multiplication.
\end{abstract}

Additional keywords: meristems; micropropagation; Saccharum officinarum; seedling production.

\begin{abstract}
Resumo
A cana-de-açúcar apresenta grande importância econômica mundial e, portanto, há grande interesse no desenvolvimento de técnicas eficientes para a produção de mudas de boa qualidade, homogêneas e livres de doenças e pragas. Uma forma de eliminar as viroses é através da cultura de meristemas. Para garantir sucesso durante 0 cultivo de meristemas faz-se necessário otimizar os componentes e concentrações do meio de cultura. A sacarose é um componente essencial no meio de cultura servindo como fonte de carbono e energia para as plântulas. O nitrogênio é um componente essencial em plantas pois participa de biomoléculas e inúmeras enzimas. O objetivo deste trabalho foi avaliar a melhor combinação de concentrações de nitrogênio $(75,100,125$ e 150\%) e sacarose $\left(0,20,30\right.$ e $\left.40 \mathrm{~g} \mathrm{~L}^{-1}\right)$ na multiplicação e no desenvolvimento in vitro de cana-de-açúcar, cultivar RB036091. O delineamento foi inteiramente casualizado, em esquema fatorial, com quatro repetições e cinco explantes por unidade experimental. A concentração de $20 \mathrm{~g} \mathrm{~L}^{-1}$ de sacarose com $100 \%$ de nitrogênio da formulação original do meio de cultura MS proporcionou melhor resposta na multiplicação de cana-de-açúcar.
\end{abstract}

Palavras-chave adicionais: meristemas; micropropagação; produção de mudas; Saccharum officinarum.

\section{Introduction}

Sugarcane (Saccharum officinarum) occupies an area of more than 27 million hectares in more than 130 countries (FAOSTAT, 2017). In the 2016/2017 harvest in Brazil, 9.1 million hectares were cultivated (CONAB, 2016), which demonstrates the great economic importance of this crop worldwide. Sugarcane is responsible for almost $70 \%$ of the world's sugar production, being also highlighted as a source for bioalcohol production. In Brazil, the planted area of sugarcane exceeds 10 million hectares, with this country being the largest producer and exporter of sugarcane by-products (UNICA, 2015).

Due to its economic importance in Brazil and its worldwide prominence, many studies are directed at the development of sugarcane genetic breeding programs (Oliveira et al., 2016). Within this scenario, tissue culture techniques have been applied in plant propagation, allowing the production of good quality, 
homogeneous, and disease- and pest-free seedlings (Kaur \& Sandhu, 2015). Other advantages are the large-scale production of seedlings in a short period of time, using a smaller area compared to conventional cultivation, and the possible increase in yield and longevity of sugarcane plantations.

The absence of plant diseases and pests is of paramount importance for good quality seedlings. Therefore, meristem culture appears an alternative for the production of healthy sugarcane plants, further guaranteeing genetic stability and the production of a large number of seedlings throughout the year (Alcantara et al., 2014). In sugarcane, meristem culture has been shown to be a potential technique for the multiplication of cultivars developed by genetic breeding programs. Many factors are involved in the in vitro multiplication of seedlings, such as asepsis and control of luminosity and temperature. Nutrition of the culture medium is also of crucial importance.

The most widely used culture medium in in vitro propagation is that formulated by Murashige \& Skoog (1962) (MS). Among the nutrients that make up this medium, nitrogen and carbon are the most supplied compounds. Sucrose is the carbon source, and potassium nitrate $\left(\mathrm{KNO}_{3}\right)$ and ammonium nitrate $\left(\mathrm{NH}_{4} \mathrm{NO}_{3}\right)$ are the nitrogen sources. The amount of nitrogen in the culture medium needs to be optimized according to plant species and growth conditions (Leljak-Levanić et al., 2004). The role of nitrogen in plant growth and development is already recognized (Malik \& Rengel, 2013), being essential in plant physiology and nutrition as an essential component of proteins, amino acids, nucleic acids, and other nitrogenous compounds that promote plant growth and development (Tripathi \& Raghubanshi, 2014). The amount and source of nitrogen used also influence the growth of in vitro cultures, their chemical metabolism, and the formation and production of metabolites (Russowski \& Nicoloso, 2003).

In sugarcane, nitrogen stimulates shoot meristem activity, which results in higher tillering rate and leaf area index. The demand for this nutrient varies according to the cultivar (Uribe et al., 2013). Nitrogen uptake depends on the availability of energy from carbohydrates. Sugars such as sucrose have the main function of providing energy for the metabolic reactions of plants, or providing carbon molecules for biosynthetic processes (Ferreira et al., 2016; Rocha et al., 2013).

In the traditional in vitro culture method, vitroplants do not receive adequate light for photosynthesis. Therefore, the nutrient medium must be supplemented with sucrose, the carbon source of culture media (Rocha et al., 2013). Being the carbon-nitrogen interaction responsible for plant development (Gabryszewska, 2015; Badr et al., 2015), it is important to determine which concentrations are ideal for in vitro plant development. Thus, the potential of these plants can be better exploited, ensuring a high multiplication rate and material savings with the use of lower con- centrations of sucrose and, consequently, lower costs.

Cultivar RB036091 presents excellent sprouting and high tillering, as well as closure between rows. It is highly resistant to the main diseases, and agricultural production is highly stable. The cultivar stands out for its rapid initial growth and yield potential, being quite responsive to environment improvement (Daros et al., 2015).

In this way, the present work evaluates the best combination of sucrose and nitrogen concentrations in the in vitro multiplication and development of sugarcane (RB036091) isolated from meristems.

\section{Material and methods}

Sugarcane plants of the cultivar RB036091, with one month of cultivation from billets, were cultivated in a greenhouse with daily irrigation and average temperature ranging from 18 to $25^{\circ} \mathrm{C}$. Immature leaves (approximately $2 \times 10 \mathrm{~cm}$ cylinder) were disinfected by treating with $70 \%(\mathrm{v} / \mathrm{v})$ ethanol for 1 minute, being then rinsed three times with autoclaved distilled water, incubated for 20 minutes in sodium hypochlorite solution with $2 \%$ active chlorine, and again rinsed three times with autoclaved distilled water. Transverse segments of the meristematic region were removed, and meristems were isolated with the aid of a stereomicroscope in a laminar flow chamber.

After isolation, meristems were inoculated in liquid MS medium (Murashige \& Skoog, 1962) supplemented with $100 \mathrm{mg} \mathrm{L}^{-1}$ myo-inositol, $0.1 \mathrm{mg} \mathrm{L}^{-1}$ kinetin, $0.2 \mathrm{mg} \mathrm{L}^{-1}$ 6-benzylaminopurine (BAP), $30 \mathrm{~g} \mathrm{~L}^{-1}$ sucrose, and $6 \mathrm{~g} \mathrm{~L}^{-1}$ agar. The medium was autoclaved at $121^{\circ} \mathrm{C}$, at $1.5 \mathrm{~atm}$, with $\mathrm{pH}$ adjusted to 5.8 before autoclaving.

The multiplication phase was performed in MS medium supplemented with $100 \mathrm{mg} \mathrm{L}^{-1}$ myo-inositol, $0.1 \mathrm{mg} \mathrm{L}^{-1}$ kinetin, $0.2 \mathrm{mg} \mathrm{L}^{-1}$ BAP, $30 \mathrm{~g} \mathrm{~L}^{-1}$ sucrose, and $\mathrm{pH} 5.8$ before autoclaving. Cultures were maintained at $25 \pm 2{ }^{\circ} \mathrm{C}$, in the dark, for 7 days. For sprout induction, cultures were maintained under cold white fluorescent light, with photon flux density of $30 \mathrm{~mol}^{-2} \mathrm{~s}^{-1}$ and $16 \mathrm{~h}$ photoperiod, for 60 days (corresponding to the other phases).

Replicates were performed in laminar flow chamber, every 15 days, in a total of four subcultures. In the fifth subculture, the shoots were transferred to liquid MS medium with changes in nitrogen $(75,100$, 125 , and $150 \%$ ) and sucrose (20, 30 and, $\left.40 \mathrm{~g} \mathrm{~L}^{-1}\right)$ concentrations. The concentrations corresponded to $\mathrm{N}$ : $75 \%$ - $1237.5 \mathrm{mg} \mathrm{L}^{-1} \mathrm{NH}_{4} \mathrm{NO}_{3}$ and $1435.0 \mathrm{mg} \mathrm{L}^{-1}$ $\mathrm{KNO}_{3} ; \mathrm{N}: 100 \%-1650.0 \mathrm{mg} \mathrm{L}^{-1} \mathrm{NH}_{4} \mathrm{NO}_{3}$ and 1900.0 $\mathrm{mg} \mathrm{L}^{-1} \mathrm{KNO}_{3} ; \mathrm{N}: 125 \%-2062.5 \mathrm{mg} \mathrm{L}^{-1} \mathrm{NH}_{4} \mathrm{NO}_{3}$ and $2375.0 \mathrm{mg} \mathrm{L}^{-1} \mathrm{KNO}_{3}$; $\mathrm{N}: 150 \%-2475.0 \mathrm{mg} \mathrm{L}^{-1} \mathrm{NH}_{4} \mathrm{NO}_{3}$ and $2650.0 \mathrm{mg} \mathrm{L}^{-1} \mathrm{KNO}_{3}$.

The experiment was conducted in a completely randomized design, in a $4 \times 4$ factorial scheme (4 nitrogen concentrations and 4 sucrose concentrations), consisting of 16 treatments with four replicates, each replicate consisting of five explants of approxi- 
mately $3.0 \mathrm{~cm}$. The treatments were formed by combinations of four nitrogen concentrations $(75,100,125$, and $150 \%)$ and three sucrose concentrations (20, 30, and $40 \mathrm{~g} \mathrm{~L}^{-1}$ ) plus the control (without sucrose). After 15 days, the following variables were evaluated: shoot height $(\mathrm{cm})$, number of leaves, number of shoots, and fresh weight (g). Data were submitted to ANOVA and regression analysis was performed with the Sisvar ${ }^{\circledR}$ program (Ferreira, 2011).

\section{Results and discussion}

The results of the analysis of variance showed homogeneous variances for the variables analyzed in the treatments. The analysis also revealed that the interaction between sucrose and nitrogen concentration was statistically significant, indicating the dependence of the factors.

For $75 \%$ nitrogen, shoot height showed a linear decrease with the increase of sucrose concentration, with the highest height being reached with $20 \mathrm{~g} \mathrm{~L}^{-1}$ sucrose. For $100 \%$ nitrogen, the concentration of $20 \mathrm{~g} \mathrm{~L}^{-1}$ sucrose was also the one that showed the highest shoot height, with a subsequent decrease in height with $30 \mathrm{~g} \mathrm{~L}^{-1}$ and a slight increase with $40 \mathrm{~g} \mathrm{~L}^{-1}$ sucrose. For the concentrations of 125 and $150 \%$ nitrogen, regression curves showed a quadratic behavior, with higher shoot heights in the concentration of $20 \mathrm{~g} \mathrm{~L}^{-1}$ sucrose (Figure 1).

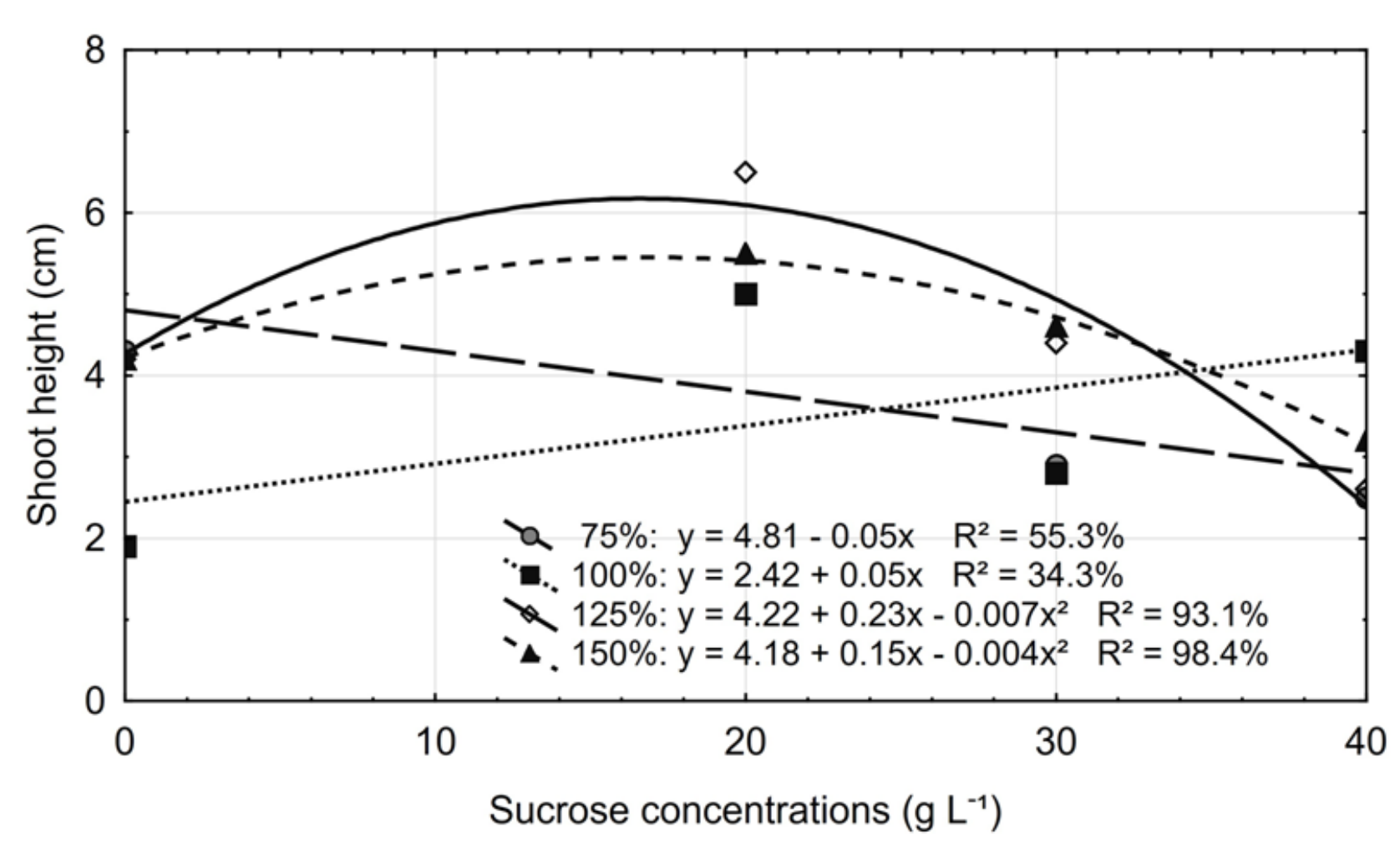

Figure 1 - Shoot height $(\mathrm{cm})$ of Saccharum officinarum 'RB 036091' as function of nitrogen and sucrose concentrations.

For the number of leaves per explant (Figure 2), number of shoots per explant (Figure 3), and shoot fresh weight (Figure 4), regression curves showed quadratic behavior, reaching higher responses with concentration close to $20 \mathrm{~g} \mathrm{~L}^{-1}$ sucrose, for all nitrogen concentrations. For shoot growth and quality, the sucrose concentration $\left(20 \mathrm{~g} \mathrm{~L}^{-1}\right)$ showed better responses for all nitrogen concentrations tested. However, the concentration of $1650 \mathrm{mg} \mathrm{L}^{-1} \mathrm{NH}_{4} \mathrm{NO}_{3}$ and $1900.0 \mathrm{mg} \mathrm{L}^{-1} \mathrm{KNO}_{3}$, which corresponds to $100 \%$ nitrogen, showed the best results.

A possible explanation for the fact that the sugarcane shoots formed in the present study did not present a positive effect with increased nitrogen concentration may be related to the fact that the plants are associated with nitrogen-fixing bacteria. Donato et al. (2004) evaluated the enzymatic activity of in vitro cultivated sugarcane varieties and found that the reduction of nitrogen levels did not affect the content of chlorophyll $a$ and $b$, since nitrogen is one of the constituents of chlorophyll. The authors also verified that the constitutive activity of nitrate reductase and glutamine synthetase were also not affected. The presence of a constitutive nitrate reductase being expressed in the absence of nitrate, as well as the nonvariation in chlorophyll content, can be explained by both the fact that sugarcane is a nitrogen-fixing species and the fact that the sugarcane varieties evaluated are associated with nitrogen-fixing bacteria. 


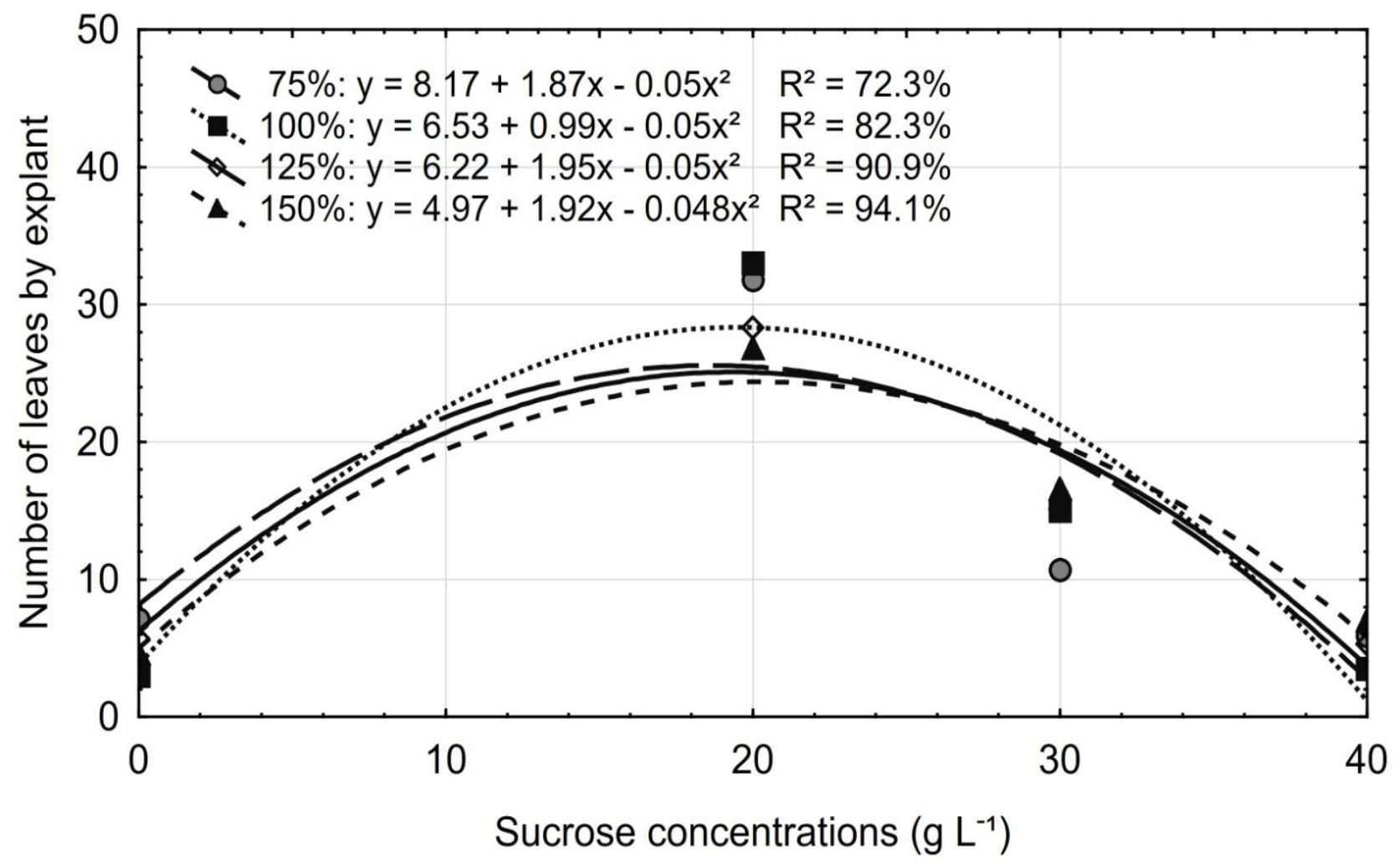

Figure 2 - Number of leaves by explant of Saccharum officinarum 'RB 036091' as function of nitrogen and sucrose concentrations.

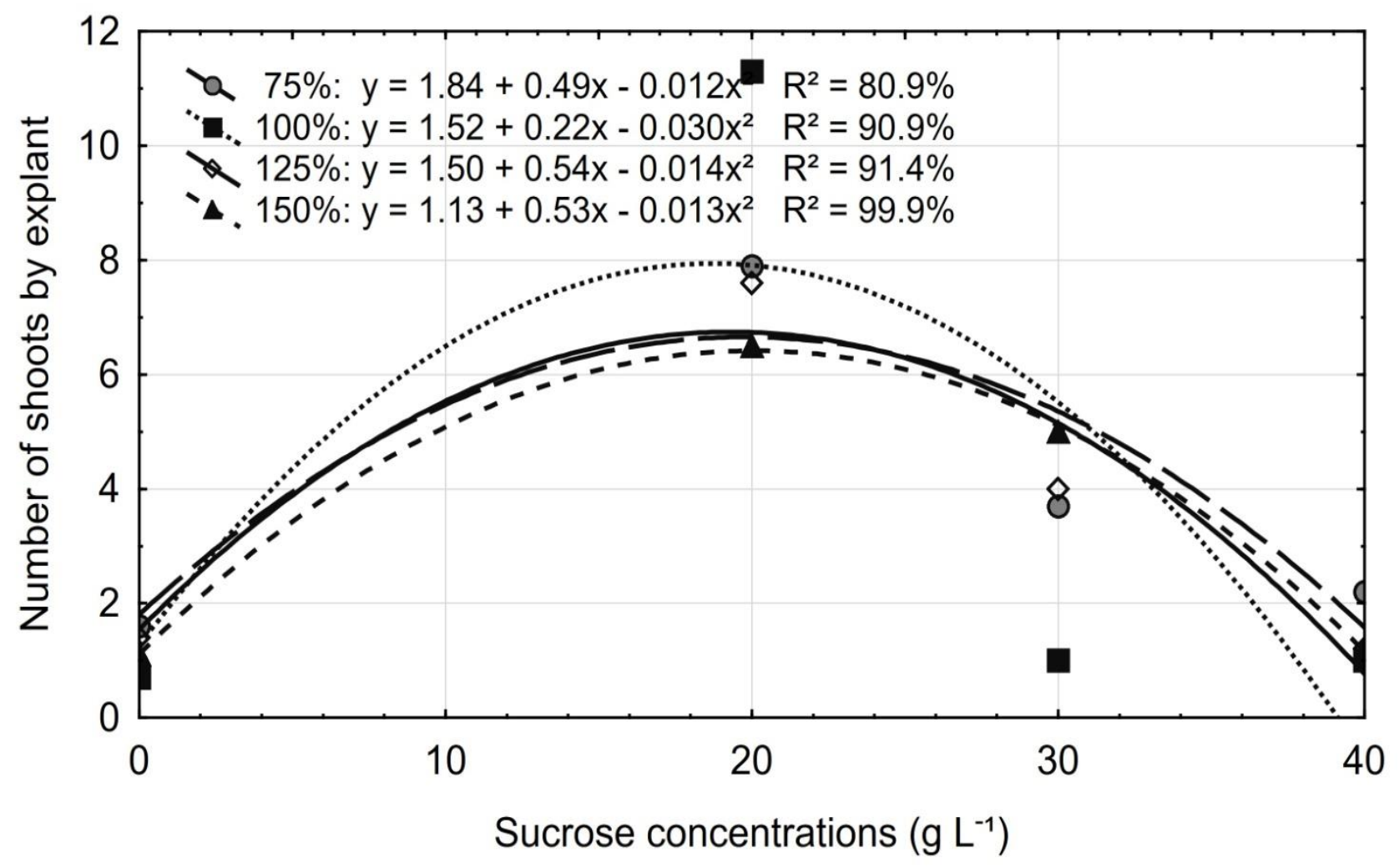

Figure 3 - Number of shoots by explant of Saccharum officinarum 'RB 036091' as function of nitrogen and sucrose concentrations. 


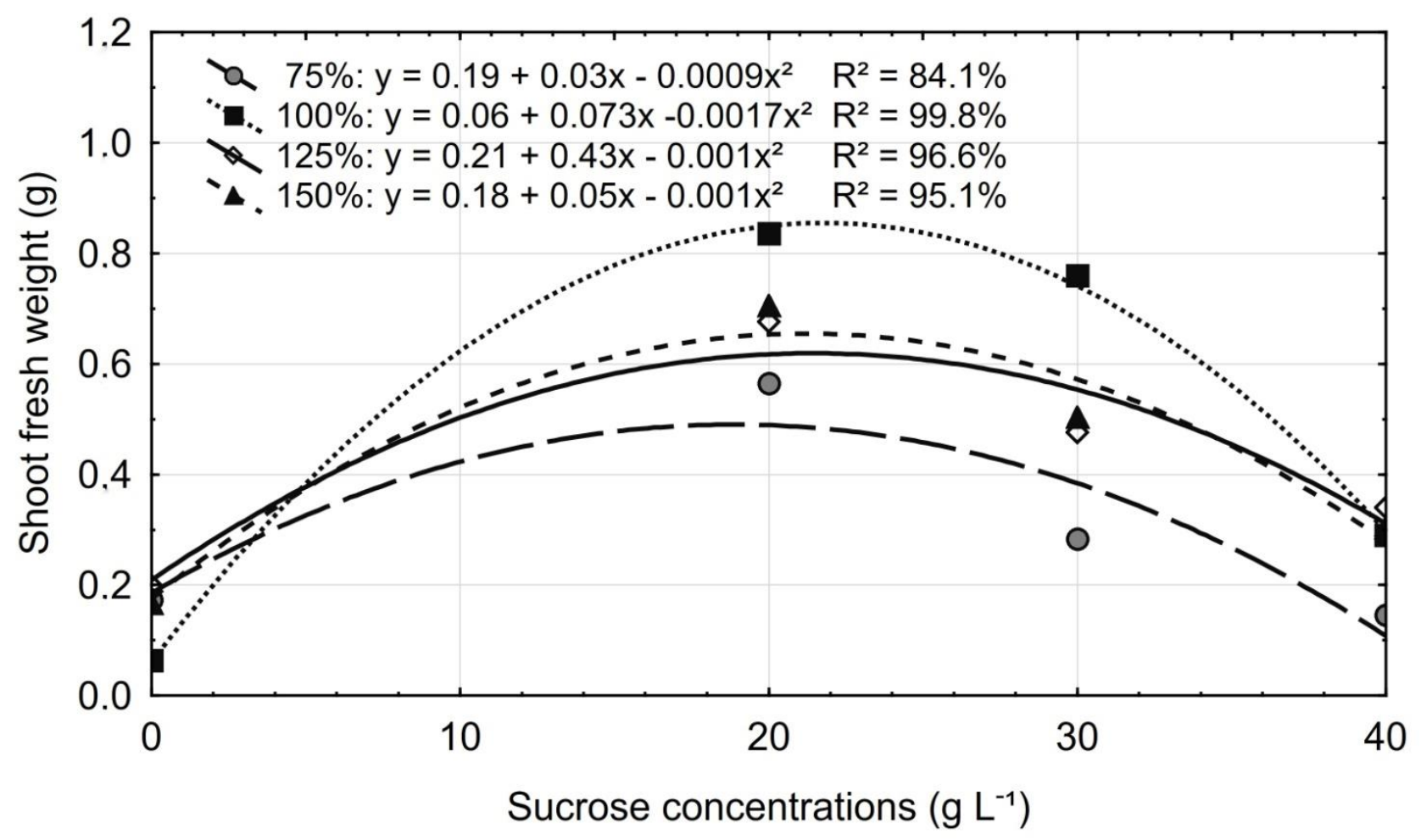

Figure 4 - Shoot fresh weight of Saccharum officinarum 'RB 036091' as function of nitrogen and sucrose concentrations.

Results similar to those of the present study were observed in Aechmea blanchetiana for the variable leaf fresh weight, which decreased linearly with the increase of nitrogen concentration in the modified MS medium, where for each added $\mathrm{mM}$ of nitrogen there was a decrease of $0.0008 \mathrm{~g}$ in biomass (Kanashiro et al., 2007). For Sinningia allagophylla grown in culture medium with different concentrations of nitrate, the number of leaves did not present significant difference (Gomes \& Shepherd, 2000). However, results contrasting to the present work were verified in the in vitro multiplication of shoots of citrus rootstocks, in which twice the concentration of nitrogen present in MS culture medium provided the best results for the number of new shoots and shoot length (Nagao et al., 1994). Notwithstanding, it has been reported a physiological and molecular correlation of carbon and nitrogen metabolism in plant growth; the presence of reduced carbon, mainly sucrose, stimulates nitrate assimilation (Jin et al., 2015). Nitrogen, together with sucrose, are the major components in the culture medium, contributing effectively both to cell metabolism and to the regulation of osmotic potential (Nagao et al., 1994).

The effect on shoot number and quality, as evidenced by the number of leaves per explant, number of shoots per explant, and shoot fresh weight (Figures 2, 3, and 4, respectively), showed different responses according to sucrose concentration. The best responses for these variables were verified at the concentration of $20 \mathrm{~g} \mathrm{~L}^{-1}$, that is, a lower concentration than that commonly used in in vitro cultivation $\left(30 \mathrm{~g} \mathrm{~L}^{-1}\right)$ for many species. Langford \& Wainwright (1987) cultivated rose shoots at different sucrose concentrations $\left(0-40 \mathrm{~g} \mathrm{~L}^{-1}\right)$ and did not find growth in culture medium without sucrose; however, a significant increase was observed when the sucrose concentration was reduced to $10 \mathrm{~g} \mathrm{~L}^{-1}$. Other authors have reported the positive effect of reducing sucrose concentrations, mainly associated with the success of acclimatization (Leite et al., 2000). This is because sucrose concentrations, normally used in tissue culture, may inhibit chlorophyll synthesis (Regueira et al., 2018). In the presence of sugars, seedlings do not develop photoautotrophic capacity, which can cause reduced growth and death of seedlings during the acclimatization phase (Shin et al., 2013; Shin et al., 2014). Some authors suggest to reduce the sucrose concentration in the last phase of in vitro cultivation aiming to promote increased photosynthesis and to accustom the plants to autotrophic nutrition conditions (Gribaudo \& Fronda, 1993). Testing the influence of sucrose on photosynthesis and transpiration of Actinidia deliciosa explants grown in vitro, Argita et al. (2002) observed better results with $20 \mathrm{~g} \mathrm{~L}^{-1}$ sucrose. The explants were exposed to $600 \mu \mathrm{mol} \mathrm{CO}_{2}$ in the first 20 days, being then transferred to culture medium without sucrose until the end of the culture period. The same authors report that this condition provided development of the photosynthetic apparatus and better acclimatization.

Some authors defend the increase or maintenance of sucrose concentration aiming at an accumu- 
lation of the carbohydrate reserves stored by the leaves, increasing the energy available to the seedlings during the processes of rooting (Rocha et al., 2013) and acclimatization (Hazarika, 2003). In this sense, when evaluating the in vitro root development of sugarcane cultivar RB867515, a 50\% sucrose reduction compared to the usual concentration in culture medium (30 $\mathrm{g} \mathrm{L}^{-1}$ ) negatively influenced root development after 60 days of cultivation, where the average values of root length and root fresh and dry weight were lower than in treatments with higher sucrose concentration (Ferreira et al., 2016). In in vitro development, photosynthesis is very low and cultures are dependent on the external support of carbohydrates (Couto et al., 2014). However, in the present study, sucrose was required for the development of Saccharum officinarum shoots, although in a concentration lower than that commonly used in in vitro cultivation.

\section{Conclusions}

According to the results obtained in this study for sugarcane cultivar RB036091, we conclude that its multiplication is possible by reducing the sucrose concentration to $20 \mathrm{~g} \mathrm{~L}^{-1}$. Moreover, nitrogen concentration influences in vitro multiplication, being recommended the original concentration of the MS culture medium.

\section{References}

Alcantara GB, Machado MP, Ribeiro DS, Wippel HH, Bespalhok Filho JC, Oliveira RA, Daros E (2014) Multiplicação, alongamento e enraizamento de brotações in vitro de clones de cana-de-açúcar submetidos a diferentes concentrações de 6-benzilaminopurina e ácido giberélico. Journal of Biotechnology and Biodiversity 5(1):20-25.

Argita L, González A, Tamés RS (2002) Influence of $\mathrm{CO}_{2}$ and sucrose on photosynthesis and transpiration of Actinidia deliciosa explants cultured in vitro. Physiologia Plantarum 115(1):166-173.

Badr A, Angers P, Desjardins Y (2015) Comprehensive analysis of in vitro to ex vitro transition of tissue-cultured potato plantlets grown with or without sucrose using metabolic profiling technique. Plant Cell Tissue Organ Culture 122(2):491-508.

CONAB - Companhia Nacional de Abastecimento. Central de informações agropecuárias: safras - cana. 2016. Disponível em: <http://www.conab.gov.br>. Acesso em: 20 dez. 2017.

Couto TR, Silva JR, Torres Neto A, Carvalho VS, Campostrini E (2014) Eficiência fotossintética e crescimento de genótipos de abacaxizeiro cultivados in vitro em diferentes qualidades de luz, tipos de frasco de cultivo e concentrações de sacarose. Revista Brasileira de Fruticultura 36(2):459-466.
Daros E, Oliveira RA, Barbosa GV de S (2015) 45 anos de variedades $R B$ de cana-de-açúcar 25 anos de Ridesa. Curitiba: Editora Graciosa, p. 61.

Donato VMTS, Andrade AG, Souza ES, França JGE, Maciel GA (2004) Atividade enzimática em variedades de cana-de-açúcar cultivadas in vitro sob diferentes níveis de nitrogênio. Pesquisa Agropecuária Brasileira 39(11)1087-1093.

FAOSTAT. Food and agriculture data. 2017. Disponível em: <http://www.fao.org/faostat/en/>. Acesso em: 12 jan. 2017.

Ferreira DF (2011) Sisvar: a computer statistical analysis system. Ciência e Agrotecnologia 35(6):1039-1042.

Ferreira LT, Silva MMA, Macêdo CR, Willadino L (2016) Fonte de luz e concentração de sacarose no cultivo in vitro da cana-de-açúcar (RB867515). Plant Cell \& Micropropagation 12(2):46-52.

Gabryszewska E (2015) Effect of different sucrose and nitrogen salt levels in the medium and temperature on in vitro propagation of Helleborus niger L. Acta Agrobotanica 68(2):161-171.

Gomes MAN, Shepherd SLK (2000) Estudo de nutrição mineral in vitro relacionado à adaptação de Sinningia allagophylla (Martius) Wiehler (Gesneriaceae) às condições de cerrado. Revista Brasileira de Botânica 23(2):153-159.

Gribaudo I, Fronda A (1993). The acclimatization of micropropagated fruit trees. Rivista di Frutticolture 55(1): 75-80.

Hazarika BN (2003) Acclimatization of tissue-cultured plants. Current Science, 85(12): 1704-1712.

Jin X, Yang G, Tan C, Zhao C (2015) Effects of nitrogen stress on the photosynthetic $\mathrm{CO}_{2}$ assimilation, chlorophyll fluorescence, and sugar-nitrogen ratio in corn. Scientific Reports Nature 5:1-9.

Kanashiro S, Ribeiro R de CS, Gonçálves AN, Dias CT dos S, Jocys T (2007) Efeitos de diferentes concentrações de nitrogênio no crescimento de Aechmea blanchetiana (Baker) L.B. Sm. cultivada in vitro. Hoehnea 34(1):59-66.

Kaur A, Sandhu JS (2015) High throughput in vitro micropropagation of sugarcane (Saccharum officinarum L.) from spindle leaf roll segments: Cost analysis for agri-business industry. Plant Cell, Tissue and Organ Culture 120(1):339-350.

Langford PJ, Wainwright $\mathrm{H}$ (1987) Effects of sucrose concentration on the photosynthetic ability of rose shoots in vitro. Annals of Botany 60(6):633-640. 
Leite, GB.; Finardi, N.; Fortes, GRL (2000) Efeitos de concentrações de sacarose no meio de cultura e da intensidade luminosa no enraizamento "in vitro" do porta-enxerto de pereira oh x f97. Ciência e Agrotecnologia, Lavras, 24(2):353-357.

Leljak-Levanić D, Bauer N, Mihaljević S, Jelaska S (2004) Somatic embryogenesis in pumpkin (Cucurbita pepo L.): control of somatic embryo development by nitrogen compounds. Journal Plant Physiology 161: 229-236.

Malik Al, Rengel Z (2013) Physiology of nitrogen-use efficiency. In: Rengel Z (Org.) Improving water and nutrient-use efficiency in food production systems. United States: Wiley-Blackwell, p. 105-121.

Murashige T, Skoog FA (1962) Revised medium for rapid growth and bioassays with tobacco tissue cultures. Physiologia Plantarum 15(3):473-497.

Nagao EO, Pasqual M, Ramos JD (1994) Efeitos da sacarose e do nitrogênio inorgânico sobre a multiplicação ïn vitro"de brotações de porta-enxerto de citros. Bragantia 53(1):25-31.

Oliveira RA, Fernandez Lucius AS, Daros E, Bespalhok Filho JC, Zambon JLC, Weber H, Verissimo MAA (2016) Performance of sugarcane families at different stages of a selection program. International Sugar Journal 16(5):378-381.

Regueira M, Rial E, Blanco B, Bogo B, Aldrey A, Correa B, Varas E, Sánchez C, Vidal N (2018) Micropropagation of axillary shoots of Salix viminalis using a temporary immersion system. Trees 32(1):61-71.
Rocha PSG, Oliveira RP, Scivittaro WB (2013) Sugarcane micropropagation using light emitting diodes and adjustment in growth-medium sucrose concentration. Ciência Rural 43(7):1168-1173.

Russowski D, Nicoloso FT (2003) Nitrogênio e fósforo no crescimento de plantas de Gisnseng brasileiro (Pfaffia glomerata (Spreng.) Pedersen) cultivadas in vitro. Ciência Rural 33(1):57-63.

Shin KS, Park SY, Paek KY (2013) Sugar metabolism, photosynthesis, and growth of in vitro plantlets of Doritaenopsis under controlled microenvironmental conditions. In Vitro Cellular \& Developmental Biology Plant 49(4):445-454.

Shin KS, Park SY, Paek KY (2014) Physiological and biochemical changes during acclimatization in a Doritaenopsis hybrid cultivated in different microenvironments in vitro. Environmental and Experimental Botany 100(1):26-33.

Tripathi SN, Raghubanshi AS (2014) Seedling growth of five tropical dry forest tree species in relation to light and nitrogen gradients. Journal of Plant Ecology 7(3):250-263.

UNICA - União da Indústria de Cana-de-açúcar. 2015. Histórico do setor sucroenergético. Disponível em: <http://www.unica.com.br>. Acesso em: 20 jan. 2017.

Uribe RAM, Gava GJ de C, Saad JCC, Kolln OT (2013) Ratoon sugarcane yield integrated drip-irrigation and nitrogen fertilization. Engenharia Agrícola 33(6):1124-1133. 